\begin{tabular}{|l|l|l|}
\hline \multicolumn{2}{|c|}{ PublisherInfo } \\
\hline \hline PublisherName & $:$ & BioMed Central \\
\hline \hline PublisherLocation & $:$ & London \\
\hline \hline PublisherImprintName & $:$ & BioMed Central \\
\hline \hline
\end{tabular}

\title{
Two species of African elephants
}

\begin{tabular}{|l|l|l||}
\hline \multicolumn{2}{|c|}{ ArticleInfo } \\
\hline \hline ArticleID & $:$ & 3901 \\
\hline \hline ArticleDOI & $:$ & $10.1186 /$ gb-2001-2-12-reports0045 \\
\hline \hline ArticleCitationID & $:$ & reports0045 \\
\hline \hline ArticleSequenceNumber & $:$ & 19 \\
\hline \hline ArticleCategory & $:$ & Paper report \\
\hline \hline ArticleFirstPage & $:$ & 1 \\
\hline \hline ArticleLastPage & $:$ & 4 \\
\hline \hline & & RegistrationDate : 2001-9-19 \\
ArticleHistory & $:$ & Received $\quad: \quad 2001-9-19$ \\
& $:$ & OnlineDate $\quad$ 2001-11-28 \\
\hline \hline ArticleCopyright & $:$ & BioMed Central Ltd2001 \\
\hline \hline ArticleGrants & $:$ & \\
\hline \hline
\end{tabular}




\begin{tabular}{|l|l|l||}
\hline ArticleContext & $:$ & 13059221212 \\
\hline
\end{tabular}

\section{John C Rockett}

\section{Abstract}

Genetic evidence supports the recognition and conservation management of African forest and savannah elephants as two distinct species.

\section{Significance and context}

Considering that elephants are the largest land animal and one of the most loved by humans, it comes as something of a surprise to learn that this great banner of wildlife conservation movements the world over might in fact be composed of three species, not two. Perhaps the most important consequence of the findings of Roca et al. will be in the area of conservation. As the 'News of the Week' piece in the same issue of Science points out, instead of there simply being 500,000 African elephants, there will be a smaller number of each kind - savannah and forest elephants - making both 'species' more endangered than has hitherto been presumed.

\section{Key results}

Skin plugs were obtained from 195 individual animals from 21 geographically distinct population using biopsy darts. DNA was extracted from the biopsies, and exon and intron components of four nuclear genes were sequenced and compared between Asian, African savannah and African forest individuals. The 'genetic distance' between forest and savannah elephants is $58 \%$ of the distance between the Asian and African elephant genera.

\section{Links}

Supplementary data to Science 293:1473-1477 is freely available. It can also be accessed at the Laboratory of Genomic Diversity. 


\section{Conclusions}

The authors propose that the African elephant is divided into two separate species, Loxodonta africana (savannah elephant) and Loxodonta cyclotis (forest elephant).

\section{Reporter's comments}

Long ago, I was taught that two animals are of different species if they cannot interbreed to form fertile, viable offspring. To me this seems a logical, functional and uncomplicated definition - albeit a somewhat limited one. Perhaps the authors have stumbled on a useful alternative method of defining a species where the ability to observe or carry out the appropriate intercrosses is limited. In both the accompanying commentary in Science and the paper itself, the morphological and geographical distinctiveness of the two types of African elephant is pointed out as an indication of their uniqueness and as one of the main justifications for the study. I cannot help but wonder what the authors would find if they applied this line of reasoning to humans and compared the corresponding genetic sequence of the forest-dwelling pygmies with their African neighbors (and tallest people on Earth), the savannahdwelling Masai. The authors acknowledge that, in one particular population of forest elephants, the genetic evidence suggests there may have been "a history of limited hybridization" with their savannahdwelling brethren. This raises the question of when are two breeds genetically, physically and geographically distinct enough to be called different species. If the genetic distance between the forest and savannah elephants had been, say, only $27 \%$ of that between African and Asian elephants, would this have been sufficient to justify a claim of two African species? This report also caused me to wonder whether anyone has ever attempted to mate an African and an Indian elephant to see if they truly are different species according to the traditional definition. There is no doubt that these findings will generate much debate on what is a species. All else notwithstanding, the concept of the forest elephant as a unique species is important in at least one context, namely that of conservation. If their 'uniqueness' gives them a better chance of surviving, then their species status seems to have some definite virtue.

\section{Table of links}

Science

Supplementary data to Science 293:1473-1477

Laboratory of Genomic Diversity 


\section{References}

1. Roca AL, Georgiadis N, Pecon-Slattery J, O'Brien SJ: Genetic evidence for two species of elephant in Africa. Science. 2001, 293: 1473-1477. 0036-8075

This PDF file was created after publication. 